\title{
Assessment of oxidative damage and enzymatic antioxidant system activity on the umbilical cord blood and saliva from preterm newborns with risk factors for early-onset neonatal sepsis
}

\author{
Fábio Gonçalves Coutinho' \\ Edna Maria de Albuquerque Diniz ${ }^{1}$ \\ Ingrid Kandler ${ }^{2}$ \\ Marco Antônio Cianciarullo ${ }^{3}$ \\ Natália Rodrigues dos Santos ${ }^{4}$
}

\begin{abstract}
1. Dept. of Pediatrics - Children's Institute / FMUSP - São Paulo/SP, Brasil. 2. Dept of Pediatrics - Federal University of Espírito Santo / UFES - Espírito Santo/ES, Brasil. 3. Chief of Dept. of Neonatology - Municipal Hospital of Barueri/SP, Brasil. 4. Dept. Of Neonatology - Municipal Hospital of Barueri/SP, Brasil.
\end{abstract}

http://dx.doi.org/10.1590/1806-9282.64.10.888

\section{SUMMARY}

BACKGROUND: To determine the concentration of the Lipid Peroxidation Marker: Malondialdehyde (MDA), and Antioxidant Markers: Superoxide Dismutase (SOD), Glutathione Peroxidase (GPX), Catalase (CAL) in umbilical cord blood and in unstimulated saliva in the first 24 and 48 hours of life in the PTNB of mothers with and without risk factors for early-onset neonatal sepsis.

METHODS: Cross-sectional study with the signing of informed consent by the pregnant women and application of a standard questionnaire classifying the PTNB in Group 1 or 2.

RESULTS: Twenty-one PTNB were studied. Regarding gender, birth weight, need for oxygen, use of phototherapy, diagnosis of assumed sepsis, presence of fetal distress, number of pregnancies, type of delivery, use of corticosteroids, premature rupture of membranes, maternal fever, chorioamnionitis, APGAR at the 5th and 10th minute of life. Statistical analysis was performed with the Mann-Whitney test $(p=0.019)$ on the GPX variable of umbilical cord blood in the group of mothers with risk factors for early-onset neonatal sepsis. There was no statistical difference in the MDA, SOD, and CAT variables of the group with risk factors and in any variable of the group without risk factors.

CONCLUSION: There was an increase of the GPX concentration in the blood from the umbilical vein in the group with risk factors for early-onset neonatal sepsis. There was no statistical significance in the comparison of saliva and umbilical cord blood. There was no statistically significant difference in MDA, SOD, CAT.

KEYWORDS: Oxidative stress. Infant, Premature. Malondialdehyde. Glutathione peroxidase. Superoxide dismutase.

\section{INTRODUCTION}

Over the last 30 years, research on neonatal sepsis has not brought significant improvements for the early diagnosis of the condition. Its incidence remains high ${ }^{1}$, and it doubled from 4.5 to 9.7 cases for every 1,000 births between 1995 and $2005^{2}$. Thus, it is of the utmost importance that the risk factors for early-onset neonatal sepsis (EOS) are identified, enabling a quick diagnosis ${ }^{3}$. Several risk factors that 
can contribute to neonatal infection have been identified, and they can be categorized as environmental, neonatal, maternal.

Amongst the environmental factors are: use of infected hospital equipment, cross-contamination of preterm newborns (PTNB) through their carers, the absence of breastfeeding. Amongst neonatal factors, are important: the maturity of the PTNB immune system, and the oxidative damage represented by the free radicals (that act in moderate concentrations in physiological defense responses against pathogens and the induction of mitosis). It is known that over the first 72 hours of life there is an extreme production of free radicals in the PTNB due to the hyperoxia resulting from the transition from intrauterine life (hypoxic medium) to extrauterine, which can result in an important mediator of cell and tissue damage when associated with the low maturity of the NB antioxidant system, especially that of PTNB, thus favoring the onset of neonatal sepsis 4 .

Amongst the maternal factors, there are:

1 - Rupture of membranes ${ }^{3} 18$ hours.

2 - Maternal fever over $38^{\circ} \mathrm{C}$.

3 - Chorioamnionitis.

PTNB are more prone to develop oxidative stress than children and adults, due to their higher susceptibility to infections, inflammations, and their immature immune system. Oxidative damages are related primarily to "reactive oxygen species" through the exposure to high concentrations of oxygen. The transition from the intrauterine environment, with a partial pressure of oxygen $(\mathrm{PaO} 2)$ of $20-25 \mathrm{mmHg}$, to the extrauterine environment, with $\mathrm{PaO} 2$ around 100 $\mathrm{mmHg}^{6}$, increases the production of reactive oxygen radicals, which can be detected in the blood through the umbilical cord? .

The combination of a high concentration of oxygen, hypoxic periods during labor, and oxidative stress cause an imbalance in the antioxidant system $^{8}$. The hydroxyl radical (OH-), which is highly reactive, can damage the DNA, cause lipid peroxidation, changes in the protein structure and in the vascular permeability, and arterio-capillary fibrosis secondary to lipid peroxidation ${ }^{9-12}$.

The malondialdehyde (MDA) is the most important marker for lipid peroxidation. This aldehyde is a highly toxic molecule. Its interaction with the DNA and proteins is often referred to as potentially atherogenic and mutagenic ${ }^{13}$, and its primary source is the enzymatic peroxidation of polyunsaturated lipids and the non-enzymatic peroxidation, which involves the participation of reactive oxygen radicals, transition metals, and other free radicals ${ }^{14}$. It can be measured through the umbilical cord blood ${ }^{15}$, peripheral blood $^{16}$, and saliva ${ }^{17}$.

Amongst the antioxidant enzymes described, is the superoxide dismutase (SOD), a metalloprotein with a strong enzymatic antioxidant power. It has three different isoforms: the first, containing copper and zinc, is present in the cytoplasm; the second, containing manganese, is present in the mitochondria; and the third is present in the intracytoplasmic environment of the NB and passes on to the extracellular environment upon reaching adulthood ${ }^{18,19}$. Catalase (CAT), also known as hydroperoxidase, is present in the intracellular environment and is mostly produced mostly in the liver, transforming hydrogen peroxide into water ${ }^{20}$.

Glutathione peroxidase (GPX) is an ANTIOXIDANT enzyme present virtually in all cells. Its primary biological function is to protect the organism from oxidative damage through the detoxification of peroxides in the presence of selenium ${ }^{21-23}$.

Since PTNB do not have adequate oxidant levels due to the interruption of the transfer between the fetus and the placenta, the endogenous production is insufficient ${ }^{24,25}$. However, the GPX activity in PTNBs is two to six times higher, while the CAT activity is three times lower in neonatal tissues in comparison with adults ${ }^{26}$.

Considering that neonatal sepsis still remains as the leading cause for NB mortality, the objective of this study is to measure and compare the concentration of malondialdehyde (marker for lipid peroxidation), superoxide dismutase, glutathione peroxidase, catalase (antioxidant markers) in the umbilical cord blood and saliva from PTNB from mothers with and without risk factors for early-onset neonatal sepsis.

\section{METHODS}

This is a cross-sectional study in which information was collected from the mothers in the delivery room and the Neonatal Intensive Care Unit (NICU) of the Municipal Hospital of Barueri, São Paulo.

A total of 21 PTNB were studied between 30-36 weeks of gestation born at the Maternity and from the Neonatology department of the Municipal Hospital of Barueri, São Paulo, from June to July 2016.

We used parameters of normality according to 
the birth weight (BW), sex, and gestational age (GA) through Capurro.

Prior to the delivery, we contacted the legal guardian or the pregnant woman to explain the study and collect the signature for the Informed Consent Form. Gestational age was confirmed through Capurro. For all PTNB, we collected data according to the standard questionnaire, which contained : 1 - Maternal and obstetric history (age, weight, height, number of prenatal consultations, number of previous pregnancies, type of delivery, abortions, existence of systemic diseases, smoking, alcohol consumption, use of medication during pregnancy. 2 - Risk factors for neonatal infection: premature rupture of membranes $>18$ hours, maternal fever above $38^{\circ} \mathrm{C}$, chorioamnionitis. 3 - Neonatal history (sex, date of birth, weight, and height at birth, Apgar scores at the 5th and 10th minute of life, use of supplemental oxygen, diagnosis of suspicion of or proven early-onset neonatal sepsis, the need of phototherapy).

The PTNB were arranged into two groups. Group I: PTNB from mothers with risk factors for early-onset neonatal sepsis; Group II: PTNB from mothers with no risk factors for infection.

\section{Collection of Material}

After delayed umbilical cord clamping and the placenta expulsion for each PTNB delivery, we collected $10 \mathrm{ml}$ of blood from the umbilical cord through umbilical vein puncture in a heparin tube in the delivery room. From the NB, we collected $1 \mathrm{ml}$ of unstimulated saliva to prevent the influence of external factors, such as stress, at 24 and 48 hours of life, using direct suction through a vacuum in a dry tube. The samples were centrifuged and stored in a freezer at $-70^{\circ} \mathrm{C}$ and later forwarded to the Oral Biochemistry Laboratory of the Department of Biomaterial and Oral Biology of the Faculty of Odontology of the University of São Paulo (USP), under the responsibility of Dr. Fernando Neves Nogueira. Spectrophotometry analysis of $\mathrm{GPX}^{27}$ and $\mathrm{SOD}^{28}$ were carried out. The MDA analysis was carried out through an estimate of the reactive substances of thiobarbituric acid ${ }^{29}$, and the CAT analysis through the decomposition of the hydrogen peroxide ${ }^{30}$.

\section{Statistical analysis}

Based on evidence found in the literature ${ }^{31}$ that the risk group for early-onset neonatal sepsis would have an average level of MDA of 10.1 and standard deviation of 2.8 , and the group with no risk factors an average of 4.2 and a standard deviation of 2.5 for a $5 \%$ probability of committing an alpha error and a statistical power of $80 \%$, it would be necessary to have 7 PTNB in each group.

We studied 21 PTNB between 30-36 weeks of gestation.

We applied the Shapiro-Wilk normality test. For the variables that rejected it, we applied the Mann-Whitney nonparametric test. For all other variables, the parametric t-test was used to obtain the averages.

We only found a statistically significant difference in the glutathione peroxidase variable from the umbilical cord blood (Table 3). In this variable, we can say that the risk factor group presents higher values of glutathione peroxidase than the group with no risk factors.

For all other variables, we found no statistically significant difference between the groups.

\section{Results}

This is a prospective cross-sectional study in which were included 21 premature infants according to the inclusion criteria.

We collected data from the PTNB at birth.

The variables selected were: sex, classification according to the weight at birth, Apgar score at the 5th and 10th minute of life, use of 100\% oxygen, phototherapy, premature rupture of membranes, maternal fever, chorioamnionitis, assumed sepsis, neonatal stress, number of previous pregnancies, type of delivery, smoking, alcohol consumption, and use of corticosteroids.

As for sex, $47.6 \%$ were males and $52.4 \%$ females (Table 1). Regarding the classification of birth weight, 19\% were SGA, $71.4 \%$ AGA, and 9.5\% LGA (Table 1). As for the use of $100 \%$ supplemental oxygen, $61.9 \%$ used it, and 38.1\% did not (Table 1). As for the use of phototherapy, 100\% did not go through it (Table 1). As for the diagnosis of assumed sepsis, 9.5\% had the diagnosis, and $90.5 \%$ did not (Table 1). As for the variable of fetal distress, $14.3 \%$ presented it, and $85.7 \%$ did not (Table 1). As for the number of previous pregnancies, 33.3\% had one pregnancy, 38.1\% had two. $19 \%$ had four, $9.5 \%$ had five (Table 1). As for the type of delivery, $33.3 \%$ had a vaginal birth, $28.6 \%$ an elective cesarean, and $38.1 \%$ an emergency cesarean (Table 1). As for smoking and alcohol consumption, $100 \%$ of the mothers declared not having either habits (Table 
TABLE 1 - SAMPLE CHARACTERIZATION: ABSOLUTE VALUES AND PERCENTAGES ACCORDING TO GROUP

\begin{tabular}{|c|c|c|c|c|c|c|}
\hline \multirow[t]{2}{*}{ Variables } & \multicolumn{2}{|c|}{ With factors } & \multicolumn{2}{|c|}{ Without factors } & \multicolumn{2}{|c|}{ Total } \\
\hline & $\mathrm{n}$ & $\%$ & $n$ & $\%$ & $\mathrm{n}$ & $\%$ \\
\hline \multicolumn{7}{|l|}{ Gender } \\
\hline Men & 5 & 41.7 & 5 & 55.6 & 10 & 47.6 \\
\hline Female & 7 & 58.3 & 4 & 44.4 & 11 & 52.4 \\
\hline \multicolumn{7}{|c|}{ Classification per weight } \\
\hline SGA & - & - & 4 & 44.4 & 4 & 19.0 \\
\hline AGA & 12 & 100.0 & 3 & 33.3 & 15 & 71.4 \\
\hline LGA & - & - & 2 & 22.2 & 2 & 9.5 \\
\hline \multicolumn{7}{|l|}{$100 \%$ Oxygen } \\
\hline Yes & 9 & 75.0 & 4 & 44.4 & 13 & 61.9 \\
\hline No & 3 & 25.0 & 5 & 55.6 & 8 & 38.1 \\
\hline \multicolumn{7}{|l|}{ Phototherapy } \\
\hline Yes & - & - & - & - & - & - \\
\hline No & 12 & 100.0 & 9 & 100.0 & 21 & 100.0 \\
\hline \multicolumn{7}{|l|}{ Assumed sepsis } \\
\hline Yes & 2 & 16.7 & - & - & 2 & 9.5 \\
\hline No & 10 & 83.3 & 9 & 100.0 & 19 & 90.5 \\
\hline \multicolumn{7}{|l|}{ Neonatal stress } \\
\hline Yes & - & - & 3 & 33.3 & 3 & 14.3 \\
\hline No & 12 & 100.0 & 6 & 66.7 & 18 & 85.7 \\
\hline \multicolumn{7}{|c|}{ Number of pregnancies } \\
\hline One & 7 & 58.3 & - & - & 7 & 33.3 \\
\hline Two & 3 & 25.0 & 5 & 55.6 & 8 & 38.1 \\
\hline Four & 2 & 16.7 & 2 & 22.2 & 4 & 19.0 \\
\hline Five & - & - & 2 & 22.2 & 2 & 9.5 \\
\hline \multicolumn{7}{|l|}{ Type of delivery } \\
\hline Vaginal & 7 & 58.3 & - & - & 7 & 33.3 \\
\hline Elec. Cesarean & 3 & 25.0 & 3 & 33.3 & 6 & 28.6 \\
\hline Emer. Cesarean & 2 & 16.7 & 6 & 66.7 & 8 & 38.1 \\
\hline \multicolumn{7}{|l|}{ Smoker } \\
\hline Yes & - & - & - & - & - & - \\
\hline No & 12 & 100.0 & 9 & 100.0 & 21 & 100.0 \\
\hline \multicolumn{7}{|c|}{ Alcohol consumption } \\
\hline Yes & - & - & - & - & - & - \\
\hline No & 12 & 100.0 & 9 & 100.0 & 21 & 100.0 \\
\hline \multicolumn{7}{|c|}{ Use of corticosteroids } \\
\hline Yes & 4 & 33.3 & 1 & 11.1 & 5 & 23.8 \\
\hline No & 8 & 66.7 & 8 & 88.9 & 16 & 76.2 \\
\hline \multicolumn{7}{|c|}{ Premature rupture of membranes } \\
\hline Yes & 4 & 33.3 & - & - & 4 & 19.0 \\
\hline No & 8 & 66.7 & 9 & 100.0 & 17 & 81.0 \\
\hline \multicolumn{7}{|l|}{ Maternal Fever } \\
\hline Yes & - & - & - & - & - & - \\
\hline No & 12 & 100.0 & 9 & 100.0 & 21 & 100.0 \\
\hline \multicolumn{7}{|l|}{ Chorioamnionitis } \\
\hline Yes & 2 & 16.7 & - & - & 2 & 9.5 \\
\hline No & 10 & 83.3 & 9 & 100.0 & 19 & 90.5 \\
\hline Total & 12 & 100.0 & 9 & 100.0 & 21 & 100.0 \\
\hline
\end{tabular}


1). As for the use of corticosteroids for lung maturation, $23.8 \%$ used, and $76.2 \%$ did not (Table 1).

As for risk factors for early neonatal sepsis: premature rupture of membranes $-19 \%$ had it, $81 \%$ did not (Table 1); maternal fever - 100\% did not have it (Table 1); chorioamnionitis - 9.5\% had it, 90.5\% did not (Table 1).

The PTNB presented Apgar scores between 8-10 at the 5th minute of life, with a mean of 9 , and between 9-10 at the 10th minute of life, with a mean of 9 as well (Table 2).

In the group with no risk factors, the MDA, CAT, SOD, and GPX behaved similarly. For the MDA and CAT, the highest values were found in the blood from the umbilical cord. As for SOD and GPX, the concentration in the saliva at 24 and 48 hours of life was greater than in the blood from the umbilical cord.

There was an statistically significant difference $(\mathrm{P}=0.019)$ in the group with risk factors for the variable of GPX in the blood from the umbilical cord. In this variable, we can say that the risk factor group presents higher values of GPX than the group with no risk factors.

For all other variables, we found no statistically significant difference between the groups.

\section{DISCUSSION}

In the present study, we analyzed 21 PTNB, out of which 12 (57.2\%) were placed in Group I, with risk factors for early-onset neonatal sepsis, and 9 (42.8\%) were placed in Group II, with no risk factors for neonatal sepsis.

There was a statistically significant difference $(\mathrm{P}=0.019)$ in the group with risk factors for the variable of GPX in the blood from the umbilical cord. In this variable, we can say that the group with risk factors for early-onset neonatal sepsis presents higher values of GPX than the group with no risk factors.

That unbalance is also found in cases of clinical or proven neonatal sepsis, in which levels of

TABLE 2 - SAMPLE CHARACTERIZATION: DESCRIPTIVE STATISTICS ACCORDING TO GROUP

\begin{tabular}{|c|c|c|c|c|c|c|c|}
\hline Groups & Variables & $\mathrm{n}$ & $\begin{array}{l}\text { Lower } \\
\text { value }\end{array}$ & $\begin{array}{l}\text { Higher } \\
\text { value }\end{array}$ & Mean & Average & $\begin{array}{l}\text { Standard } \\
\text { deviation }\end{array}$ \\
\hline \multirow[t]{3}{*}{ With factors } & Birth weight (g) & 12 & $1,390.00$ & $3,270.00$ & $2,355.00$ & $2,308.33$ & 587.62 \\
\hline & 5th minute Apgar & 12 & 8.00 & 10.00 & 9.00 & 9.25 & 0.75 \\
\hline & 10th minute Apgar & 2 & 9.00 & 10.00 & 9.50 & 9.50 & 0.71 \\
\hline \multirow{3}{*}{$\begin{array}{l}\text { Without } \\
\text { factors }\end{array}$} & Birth weight (g) & 9 & $1,270.00$ & $3,855.00$ & $2,235.00$ & $2,356.67$ & 768.14 \\
\hline & 5th minute Apgar & 9 & 8.00 & 10.00 & 9.00 & 9.22 & 0.67 \\
\hline & 10th minute Apgar & 1 & 9.00 & 9.00 & 9.00 & 9.00 & - \\
\hline \multirow[t]{3}{*}{ TOTAL } & Birth weight (g) & 21 & $1,270.00$ & $3,855.00$ & $2,300.00$ & 2,329.05 & 653.09 \\
\hline & 5th minute Apgar & 21 & 8.00 & 10.00 & 9.00 & 9.24 & 0.70 \\
\hline & 10th minute Apgar & 3 & 9.00 & 10.00 & 9.00 & 9.33 & 0.58 \\
\hline
\end{tabular}

TABLE 3 - DESCRIPTIVE STATISTICS AND RESULTS OF THE COMPARATIVE TESTS - BLOOD FROM THE UMBILICAL CORD

\begin{tabular}{|c|c|c|c|c|c|}
\hline $\begin{array}{l}\text { Variables } \\
\text { (blood) }\end{array}$ & Groups & Mean & Average & $\begin{array}{l}\text { Standard } \\
\text { deviation }\end{array}$ & $p$-value \\
\hline \multirow[t]{2}{*}{ Protein } & With factor & 190.8165 & 195.9479 & 34.1258 & \multirow[t]{2}{*}{$0.570^{\star *}$} \\
\hline & Without factor & 189.4390 & 228.6762 & 96.5989 & \\
\hline \multirow[t]{2}{*}{ MDA } & With factor & 0.0271 & 0.0281 & 0.0052 & \multirow[t]{2}{*}{$0.286^{\star *}$} \\
\hline & Without factor & 0.0313 & 0.0295 & 0.0041 & \\
\hline \multirow[t]{2}{*}{ Catalase } & With factor & 0.1896 & 0.1922 & 0.0374 & \multirow[t]{2}{*}{$0.366^{\star}$} \\
\hline & Without factor & 0.1487 & 0.1628 & 0.0875 & \\
\hline \multirow[t]{2}{*}{ Glutathione peroxidase } & With factor & 0.2285 & 0.2465 & 0.1793 & \multirow[t]{2}{*}{$0.019^{\star \star}$} \\
\hline & Without factor & 0.0791 & 0.0792 & 0.0220 & \\
\hline \multirow[t]{2}{*}{ SOD } & With factor & 0.0051 & 0.0054 & 0.0016 & \multirow[t]{2}{*}{$0.067^{\star}$} \\
\hline & Without factor & 0.0039 & 0.0041 & 0.0014 & \\
\hline
\end{tabular}

${ }^{*}$ t-Test for averages. ${ }^{*}$ Mann-Whitney Test 


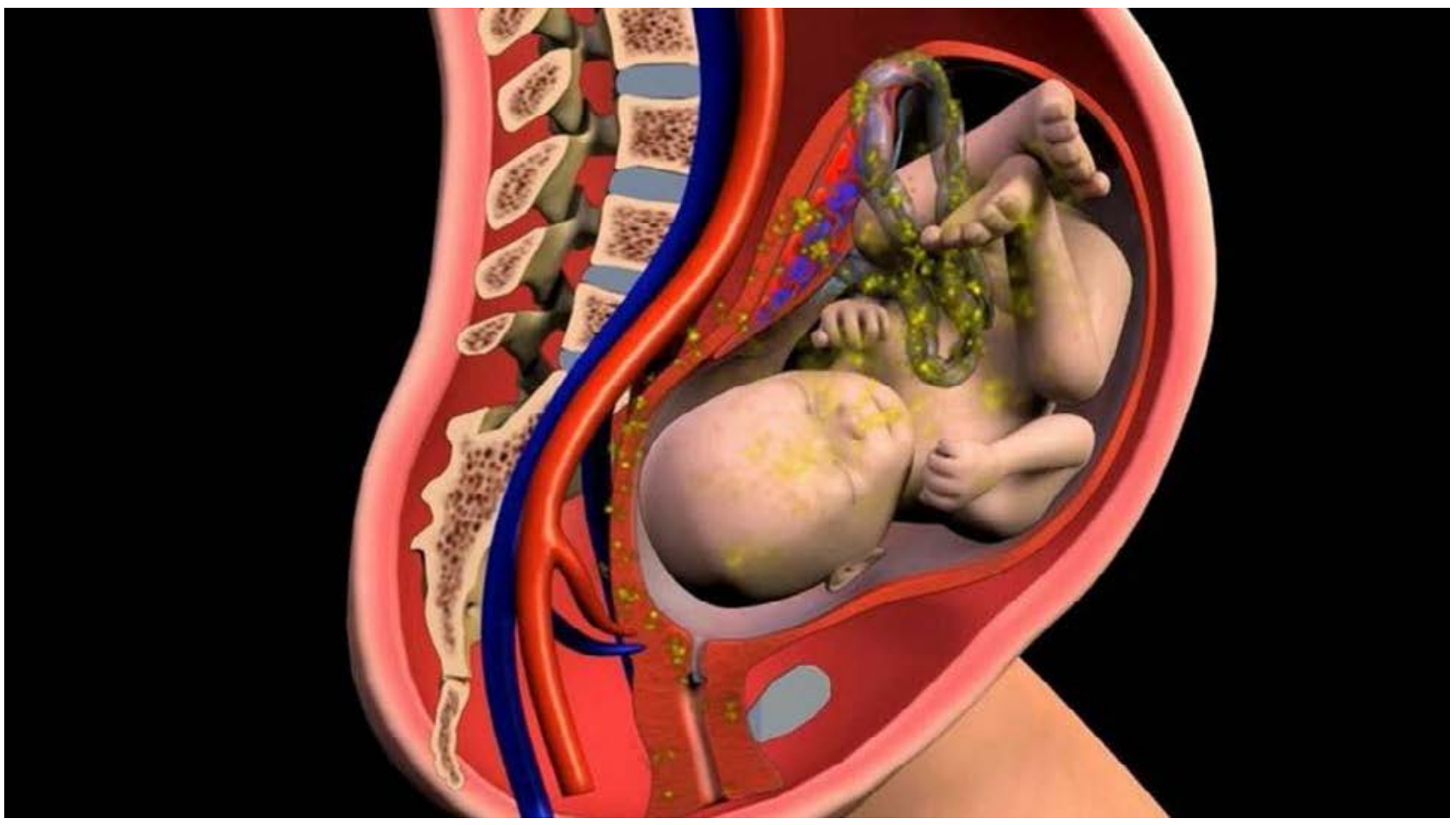

FIGURE 1

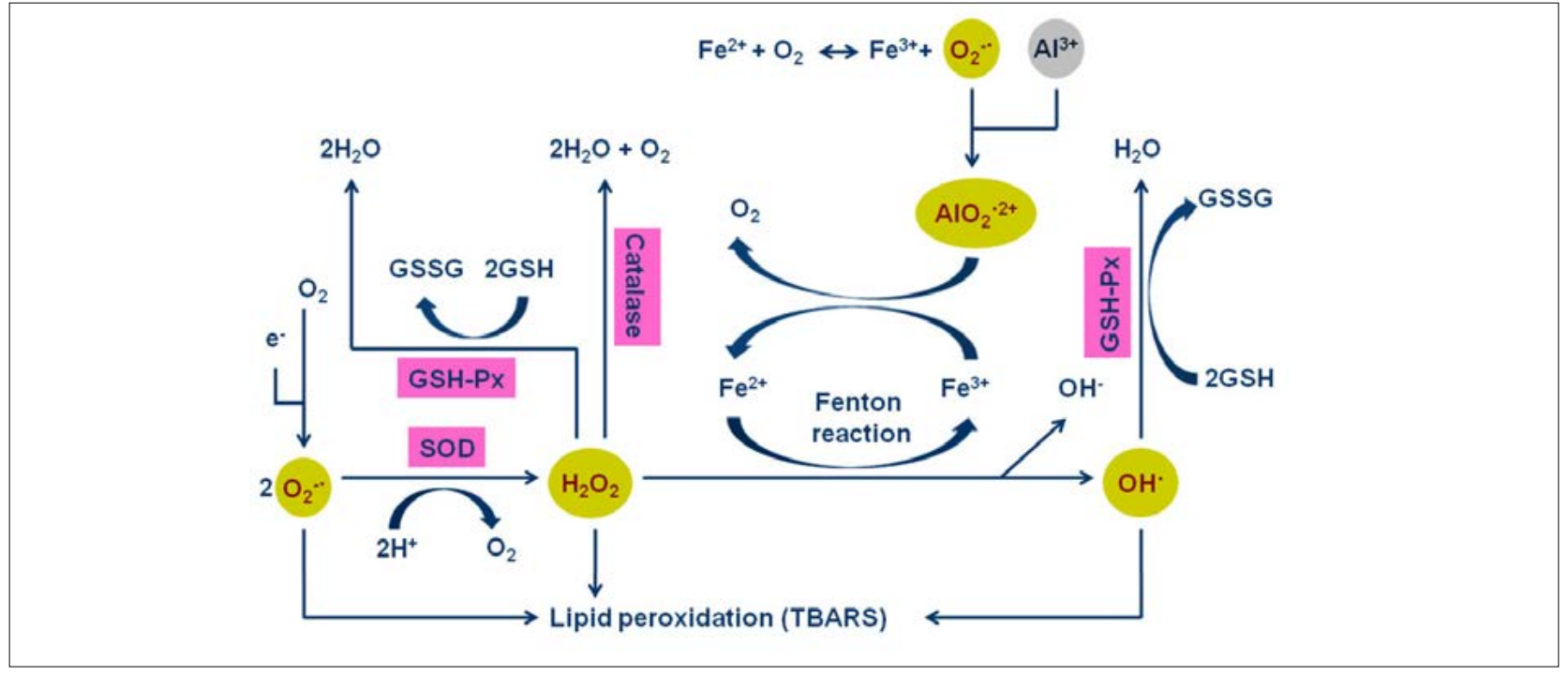

FIGURE 2

lipid peroxidation rise. There is also a significant increase of GPX in these cases of clinical neonatal sepsis $^{32}$. A pediatrics study with 84 children -42 with clinical sepsis and 42 healthy - showed that the concentration of GPX was higher $(\mathrm{P}<0.001)$ in the presence of sepsis than in patients from the control group ${ }^{33}$.

In this group, were also found higher concentrations of MDA and CAT in the blood from the umbilical cord, with no statistical difference in the saliva at $24 \mathrm{~h}$ and $48 \mathrm{~h}$ of life. In conformity with the literature, a study describes the comparison between MDA con- centrations in preterm newborns (31 PTNB) and term NB (29). It was found an MDA concentration two times greater $(\mathrm{P}=0.002)$ in PTNB than in term $\mathrm{NB}^{34}$. This difference can be explained, for the intracellular defenses against oxidative damage are lower in PTNB than in term $\mathrm{NB}^{35}$.

The concentration of SOD in the blood from the umbilical cord was lower in comparison with the concentration found in the saliva at $24 \mathrm{~h}$ and $48 \mathrm{~h}$ of life. Consistent with the literature, which presented a reduction of SOD activity in the blood from the umbilical cord, showing the possibility 
of the enzyme antioxidant protection mechanism against the increase of lipid peroxidation ${ }^{36}$.

In the group with no risk factors, MDA and CAT in the blood from the umbilical cord behaved with similar concentrations in the saliva from $24 \mathrm{~h}$ and $48 \mathrm{~h}$ of life. In a study were collected 30 blood samples from the umbilical cords from healthy NB, and the MDA analyzed showed low concentrations during labor ${ }^{37}$. However, the GPX and SOD concentrations were lower in the blood from the umbilical cord in comparison with the saliva at $24 \mathrm{~h}$ and $48 \mathrm{~h}$ of life. Several authors have shown reduced concentrations of GPX and SOD in comparison with CAT in PTNB $^{38,39}$.

Another study also describes that the concentration of GPX in health PTNB is linked to the gestational age: the more premature the newborn is, the lower the GPX concentration ${ }^{40}$.

\section{CONCLUSION}

The data from this study indicate an increase in the concentration of GPX in the blood from the umbilical vein in PTNB from the group of mothers with risk factors for sepsis in comparison with the other group. There was no statistical significance in the comparison between the saliva and the blood from the umbilical cord. There was no statistically significant difference in the MDA, SOD, and CAT variables between both groups, regarding the saliva at $24 \mathrm{~h}$ and $48 \mathrm{~h}$ of life and the blood from the umbilical cord.

The levels of GPX in the blood from the umbilical cord might be a diagnostic tool for more quickly identifying the suspicion of early-onset neonatal sepsis in PTNB of a mother with risk factors for early-onset neonatal sepsis without putting the patient under further stress.

\section{RESUMO}

OBJETIVOS: Determinar a concentração do marcador de peroxidação lipídica: Malondialdeído (MDA) e dos marcadores antioxidantes: Superóxido Dismutase (SOD), Glutationa Peroxidase (GPX), Catalase (CAL) no sangue do cordão umbilical e na saliva não estimulada nas primeiras 24 e 48 horas de vida nos RNPT de mães com e sem fatores de risco para sepse neonatal precoce.

METODOlogiA: Estudo transversal com a assinatura do termo de consentimento livre esclarecido pela gestante e aplicação de um questionário padrão classificando o RNPT no Grupo 1 ou 2.

RESULTADOS: Foram estudados 21 RNPT. Quanto ao gênero, peso ao nascimento, necessidade de oxigênio, uso de fototerapia, diagnóstico de sepse presumida, presença de sofrimento fetal, número de gestações, tipo de parto, uso de corticoide, rotura prematura de membranas, a presença de febre materna, a presença de corioamnionite. Apgar no 50 e 100 minuto de vida, a análise estatística foi feita com o teste de Mann-Whitney ( $p=0,019)$ na váriável GPX do sangue do cordão umbilical no grupo das mães com fatores de risco para sepse neonatal precoce. Não houve diferença estatística nas outras variáveis MDA, SOD, CAT do grupo com fatores de risco e em nenhuma variável do grupo sem fatores de risco.

CONCLUSÃO: O aumento de duas vezes a concentração da GPX no sangue da veia umbilical dos RNPT do grupo das mães com fatores de risco para sepse neonatal precoce. Sem significância estatística na comparação entre a saliva e o sangue do cordão umbilical. Não houve diferença estatisticamente significante nas variáveis MDA, SOD e CAT.

PALAVRAS-CHAVE: Estresse oxidativo. Recém-nascido prematuro. Malondialdeído. Glutationa peroxidase. Superóxido dismutase.

\section{REFERENCES}

1. Garenne M, Kahn K, Collinson MA, Gómez-Olivé FX, Tollman S. Materna mortality in rural South Africa: the impact of case definition on levels and trends. Int | Womens Health. 2013;5:457-63.

2. Hartman ME, Linde-Zwirble WT, Angus DC, Watson RS. Trends in the epidemiology of pediatric severe sepsis. Pediatr Crit Care Med. 2013;14(7):686-93

3. Escobar G], Puopolo KM, Wi S, Turk B], Kuzniewicz MW, Walsh EM, et al. Stratification of risk of early-onset sepsis in newborns $\geq 34$ weeks' gestation. Pediatrics. 2014;133(1):30-6.

4. Saugstad OD, Sejersted $Y$, Solberg R, Wollen EJ, Bjørås M. Oxygenation of the newborn: a molecular approach. Neonatology. 2012;101(4):315-25.

5. Mutinati $M$, Pantaleo $M$, Roncetti $M$, Piccinno $M$, Rizzo A, Sciorsci RL. Oxidative stress in neonatology: a review. Reprod Domest Anim. 2014:49(1):7-16.

6. Torres-Cuevas I, Cernada M, Nuñez A, Escobar J, Kuligowski J, Chafer-Pericas $C$, et al. Oxygen supplementation to stabilize preterm infants in the fetal to neonatal transition: no satisfactory answer. Front Pediatr. 2016;4:29.
7. Torres-Cuevas I, Parra-Llorca A, Sánchez-IIlana A, Nuñez-Ramiro A, Kuligowski J, Cháfer-Pericás $C$, et al. Oxygen and oxidative stress in the perinatal period. Redox Biol. 2017;12:674-81.

8. Marseglia L, D'Angelo G, Manti S, Arrigo T, Barberi I, Reiter RJ, et al. Oxidative stress-mediated aging during the fetal and perinatal periods. Oxid Med Cell Longev. 2014;2014:358375.

9. Perrone S, Bracciali C, Di Virgilio N, Buonocore G. Oxygen use in neonatal care: a two-edged sword. Front Pediatr. 2017;4:143.

10. Vento M, Hummler H, Dawson J, Escobar J, Kuligowski J. Use of oxygen in the resuscitation of neonates. In: Dennery P, Buonocore G, Saugstad $\mathrm{O}$, eds. Perinatal and prenatal disorders. Oxidative stress in applied basic research and clinical practice. New York: Humana Press; 2014. p.213-43.

11. Kalyanaraman $B$. Teaching the basics of redox biology to medical and graduate students: oxidants, antioxidants and disease mechanisms. Redox Biol. 2013;1:244-57.

12. Saugstad OD. Oxygen and oxidative stress in the newborn. Studies on pediatric disorders. New York: Springer; 2014. p.3-13. 
13. Abdel Ghany EA, Alsharany W, Ali AA, Youness ER, Hussein JS. Anti-oxidant profiles and markers of oxidative stress in preterm neonates. Paediatr Int Child Health. 2016;36(2):134-40.

14. Barrera G. Oxidative stress and lipid peroxidation products in cancer progression and therapy. ISRN Oncol. 2012;2012:137289.

15. El Bana SM, Maher SE, Gaber AF, Aly SS. Serum and urinary malondialdehyde (MDA), uric acid, and protein as markers of perinatal asphyxia. Electron Physician. 2016;8(7):2614-9.

16. Buonocore G, Perrone S, Longini M, Terzuoli L, Bracci R. Total hydroperoxide and advanced oxidation protein products in preterm hypoxic babies. Pediatr Res. 2000;47(2):221-4.

17. Moore TA, Wilson ME, Schmid KK, Anderson-Berry A, French JA, Berger AM. Relations between feeding intolerance and stress biomarkers in preterm infants. J Pediatr Gastroenterol Nutr. 2013;57(3):356-62.

18. Bar-Or D, Bar-Or R, Rael LT, Brody EN. Oxidative stress in severe acute illness. Redox Biol. 2015;4:340-5.

19. Zelko IN, Mariani TJ, Folz RJ. Superoxide dismutase multigene family: a comparison of the CuZn-SOD (SOD1), Mn-SOD (SOD2), and EC-SOD (SOD3) gene structures, evolution, and expression. Free Radic Biol Med. 2002;33(3):337-49.

20. Iwase T, Tajima A, Sugimoto S, Okuda K, Hironaka I, Kamata Y, et al. A simple assay for measuring catalase activity: a visual approach. Sci Rep. 2013:3:3081.

21. Mills GC. Hemoglobin catabolism. I. Glutathione peroxidase, an erythrocyte enzyme which protects hemoglobin from oxidative breakdown. I Biol Chem. 1957;229(1):189-97.

22. Nejad RK, Goodarzi MT, Shfiee G, Pezeshki N, Sohrabi M. Comparison of oxidative stress markers and serum cortisol between normal labor and selective cesarean section born neonates. J Clin Diagn Res. 2016;10(6):BC01-3.

23. Ahmed AE, Abd-Elmawgood EA, Hassan MH. Circulating protein carbonyls, antioxidant enzymes and related trace minerals among preterms with respiratory distress syndrome. J Clin Diagn Res. 2017;11(7):BC17-21.

24. Negi R, Pande D, Kumar A, Khanna RS, Khanna HD. Evaluation of biomarkers of oxidative stress and antioxidant capacity in the cord blood of preterm low birth weight neonates. I Matern Fetal Neonatal Med. 2012;25(8):1338-41.

25. Dani $C$, Poggi $C$. The role of genetic polymorphisms in antioxidant enzymes and potential antioxidant therapies in neonatal lung disease. Antioxid Redox Signal. 2014;21(13):1863-80.

26. Bajcetic M, Spasić S, Spasojević I. Redox therapy in neonatal sepsis: reasons, targets, strategy, and agents. Shock. 2014;42(3):179-84.

27. Punchard NA, Kelly FJ. Glutathione peroxidase: activity and steady-state level of mRNA. In: Daret K. St. Clair e Ching K. Chow). Free radicals: a practical approach. London: Oxford University Press; 1996. p.227-40.

28. Paoletti F, Mocali A. Determination of superoxide dismutase activity by purely chemical system based on NAD(P)H oxidation. Methods Enzymol. 1990;186:209-20.

29. Esterbauer $\mathrm{H}$, Cheeseman $\mathrm{KH}$. Determination of aldehydic lipid peroxidation products: malonaldehyde and 4-hydroxynonenal. Methods Enzymol. 1990;186:407-21

30. Aeibi H. Catalase. In: Bergmeyer HV, ed. Methods in enzymatic analysis. New York: Academic Press Inc.; 1983. p.276-80.

31. Cancelier AC, Petronilho F, Reinke A, Constantino L, Machado R, Ritter C, et al. Inflammatory and oxidative parameters in cord blood as diagnostic early-onset neonatal sepsis: a case-control study. Pediatr Crit Care Med. 2009;10(4):467-71.

32. Asci A, Surmeli-Onay O, Erkekoglu P, Yigit S, Yurdakok M, Kocer-Gumusel $B$. Oxidant and antioxidant status in neonatal proven and clinical sepsis according to selenium status. Pediatrics Int. 2015;57(6):1131-7.

33. Molina V, von Dessauer B, Rodrigo R, Carvajal C. Oxidative stress biomarkers in pediatric sepsis: a prospective observational pilot study. Redox Rep. 2017;22(6):330-7.

34. Cipierre C, Haÿs S, Maucort-Boulch D, Steghens IP, Picaud IC. Malondialdehyde adduct to hemoglobin: a new marker of oxidative stress suitable for full-term and preterm neonates. Oxidative Med Cell Longev. 2013; 2013:694014

35. Chakravarty S, Sontakke AN. A correlation of antioxidants and lipid peroxidation between maternal and cord blood in full term and preterm deliveries. Curr Pediatr Res. 2012;16(2):167-74.

36. Dede H, Takmaz O, Ozbasli E, Dede S, Gungor M. Higher level of oxidative stress markers in small for gestational age newborns delivered by cesarean section at term. Fetal Pediatr Pathol. 2017:36(3):232-9.

37. Yüksel S, Yiğit AA. Malondialdehyde and nitric oxide levels and catalase, superoxide dismutase, and glutathione peroxidase levels in maternal blood during different trimesters of pregnancy and in the cord blood of newborns. Turk J Med Sci. 2015;45(2):454-9.

38. Lázár R, Orvos $H$, Szőllősi $R$, Varga IS. The quality of the antioxidant defence system in term and preterm twin neonates. Redox Rep. 2015;20(3):103-8.

39. Díaz-Castro J, Florido J, Kajarabille N, Prados S, Paco C, Ocon O, et al. A new approach to oxidative stress and inflammatory signaling during labour in healthy mothers and neonates. Oxid Med Cell Longev. 2015;2015:178536.

40. Santos C, García-Fuentes E, Callejón-Leblic B, García-Barrera T, Gómez-Ariza JL, Rayman MP, et al. Selenium, selenoproteins and selenometabolites in mothers and babies at the time of birth. $\mathrm{Br} \mid$ Nutr. 2017;117(9):1304-11. 